\title{
Low-Temperature Growth of ZnO Nanoparticles by Using Autoclave
}

\author{
${ }^{1}$ Department of Physics, \\ Jahangirnagar University, \\ Savar, Dhaka-1342, Bangladesh \\ ${ }^{2}$ Department of Chemistry, \\ Jahangirnagar University, \\ Savar, Dhaka-1342, Bangladesh
}

A. K. M. Shahabuddin ${ }^{1}$, Nasrin Jewena ${ }^{2}$, Sujan Kumar Das ${ }^{1}$, Jahirul Islam Khandaker ${ }^{1}$, and Farid Ahmed ${ }^{1}$

Zinc-oxide nanoparticles have been synthesized by using an easy, cheap, and rapid green method, namely, hydrothermal method with the assistance of stainless-steel autoclave at two different temperatures $\left(100^{\circ} \mathrm{C}\right.$ and $\left.150^{\circ} \mathrm{C}\right)$, and their structural, optical, and chemical properties are investigated. XRD analysis identified the hexagonal wurtzite-type structure of $\mathrm{ZnO}$ nanoparticles as well as indicated that the crystallite size increased from $10.08 \mathrm{~nm}$ to $37 \mathrm{~nm}$ along with the elevated growth temperature from $100^{\circ} \mathrm{C}$ to $150^{\circ} \mathrm{C}$. The transmittance spectra showed a sharp decrease in the transmittance after crossing a certain wavelength that was the strong evidence of cut-off wavelength for the transmittance of $\mathrm{ZnO}$ nanoparticles. The observed band gaps from the Tauc plot were of $3.60 \mathrm{eV}$ and $3.05 \mathrm{eV}$ at growth temperature $100^{\circ} \mathrm{C}$ and $150^{\circ} \mathrm{C}$, respectively. The FTIR spectrum showed the incomplete removal of organic solvent. However, more organic-solvent presence was observed at high growth temperature indicating existence of more impurity compared to lower growth temperature.

Наночастинки оксиду цинку були синтезовані за допомогою простої, дешевої та швидкої зеленої методи, а саме, гідротермічної методи за допомогою автоклаву з неіржавійної криці за двох різних температур $\left(100^{\circ} \mathrm{C}\right.$ та $\left.150^{\circ} \mathrm{C}\right)$, а їхні структурні, оптичні та хемічні властивості досліджуються. Рентгенографічна аналіза виявила гексагональну вюртцитного типу структуру наночастинок $\mathrm{ZnO}$, а також показала, що розмір кристалітів збільшився від 10,08 нм до 37 нм разом із підвищеною температурою росту від $100^{\circ} \mathrm{C}$ до $150^{\circ} \mathrm{C}$. Спектри пропускання показали різке зменшення пропускання після перетину певної довжини хвилі, що стало вагомим свідченням граничної довжини хвилі для пропускання наночастинками ZnO. Спостережувані ширини забороненої (ене- 
ргетичної) зони на Тауковій ділянці становили 3,60 еВ і 3,05 еВ за температури росту у $100^{\circ} \mathrm{C}$ i $150^{\circ} \mathrm{C}$ відповідно. Інфрачервоний спектер на основі Фур'є-перетвору показав неповне видалення органічного розчинника. Однак спостерігалося більше присутности органічного розчинника за високої температури росту, що вказує на наявність більшої кількости домішок порівняно з нижчою температурою росту.

Key words: $\mathrm{ZnO}$ nanoparticles, hydrothermal method, autoclave, optical properties, XRD, FTIR.

Ключові слова: наночастинки $\mathrm{ZnO}$, гідротермічна метода, автоклавне оброблення, оптичні властивості, Рентгенівська дифракція, інфрачервона спектроскопія на основі Фур'є-перетвору.

(Received 3 July, 2020)

\section{INTRODUCTION}

Semiconducting nanomaterials have unique optical, mechanical, electrical, magnetic, electrical properties, which make promising application in the field of solar cells (photovoltaic cells), optical planar waves' guides, electronics, catalysis, optical communication, energy storage, sensing, data storage, transmission, environmental protection, cosmetics, and light emitting devices (LEDs) [1-3]. Among all of the classes of semiconducting nanomaterials, preparation and applications of the metal-oxide nanostructures play a vital role in many areas of chemistry, physics, and materials science [4, 5].

Zinc-oxide nanoparticle is one of the II-VI materials, and it has some of the advantages over the other semiconducting materials [6] such as high electron mobility with undoped state, high thermal conductivity, good transparency, large breakdown field due to high band gap. It can also be used in the high-temperature operation due to its thermal stability. It is a direct band-gap material having the direct band gap of $3.37 \mathrm{eV}$ at room temperature, and its binding energy is of $60 \mathrm{meV}$ [7], whereas the binding energy of GaN is of $28 \mathrm{meV}$ [8]. All these novel properties of $\mathrm{ZnO}$ nanoparticles have attracted the researchers to focus on synthesis, characterization and device application of $\mathrm{ZnO}$ nanomaterials. $\mathrm{ZnO}$ nanostructures have high demand in the technological application, and this demand enforces the researchers and scientists for the development of the synthesis techniques of high-quality zinc-oxide nanostructures. All of the synthesis techniques of nanomaterials can be classified in two classes. If the small building blocks congregate to form a larger structure, then it is called 'Bottom Up' method where the main controlling parameters are morphology, crystallinity, particle size, and chemical composition [9]. Another synthesis technique is named as 
'Top Down' method where the larger objects are altered into smaller structures [10]. The variety of nanostructured materials such as, nanowires [11], nanotubes, nanorings, nanotetrapods have been synthesized by chemical vapour deposition method [12], thermal evaporation method [13], sol-gel method [14], co-precipitation method [15], hydrothermal method [16-20], electrodeposition method [21], and chemical bath deposition method [22].

This research mainly focuses on the hydrothermal synthesis technique for $\mathrm{ZnO}$ nanoparticles to control over size. The hydrothermal method is a synthesis technique that grows crystals and nanocrystals using reactions in a liquid medium at elevated temperatures and pressures. There are numerous advantages of the hydrothermal method including aggregate reduction resulting in monodispersity, ability to morphological control of the final products, and crystalline product [23]. The main interest of this research work focuses on the growth parameters, which influence the synthesis of $\mathrm{ZnO}$ nanostructures in a significant scale.

\section{EXPERIMENTAL}

The $\mathrm{ZnO}$ nanomaterials were synthesized by using autoclave assist hydrothermal process. The total synthesis process was maintained under low temperature. We designed a desired shaped (cylindrical) autoclave for low-cost production of $\mathrm{ZnO}$ nanoparticles. We made such an arrangement that prevented any kind of leakage inside the autoclave, which is necessary for the production of ultrafine metaloxide nanoparticles.

Firstly, stock solutions of $\mathrm{Zn}\left(\mathrm{CH}_{3} \mathrm{COO}\right)_{2} \cdot 2 \mathrm{H}_{2} \mathrm{O}(0.1 \mathrm{M})$ was prepared in $50 \mathrm{ml}$ methanol under stirring. To this stock solution, 25 $\mathrm{ml}$ of $\mathrm{NaOH}(0.3 \mathrm{M})$ solution prepared in methanol was added under continuous stirring. Then, these solutions were transferred into stainless-steel autoclaves and maintained at various temperatures in the range of $100-150^{\circ} \mathrm{C}$ for 6 hours under autogenous pressure. It was then allowed to cool naturally to room temperature. After the reaction was complete, the resulting white solid products were washed with methanol, filtered and then dried in air in a laboratory oven at $60^{\circ} \mathrm{C}$.

All of these steps can be described as follows:

$$
\begin{gathered}
\mathrm{Zn}\left(\mathrm{CH}_{3} \mathrm{COO}\right)_{2}+\mathrm{NaOH} \rightarrow \mathrm{Zn}\left(\mathrm{CH}_{3} \mathrm{COO}\right) \mathrm{OH}+\mathrm{CH}_{3} \mathrm{COONa}, \\
\mathrm{Zn}\left(\mathrm{CH}_{3} \mathrm{COO}\right) \mathrm{OH}+\mathrm{NaOH} \rightarrow \mathrm{ZnO}+\mathrm{CH}_{3} \mathrm{COONa}+\mathrm{H}_{2} \mathrm{O} .
\end{gathered}
$$

To get fine grain powders to maximize surface area, to reduce particle size and to get a homogeneous mixture, powder was milled. 


\section{RESULTS AND DISCUSSION}

The $\mathrm{ZnO}$ nanomaterials were synthesized by using autoclave at two different temperatures (at $100^{\circ} \mathrm{C}$ and $150^{\circ} \mathrm{C}$ ) and characterized by $\mathrm{x}$ ray diffractometry (XRD), UV-Vis Spectroscopy and Fouriertransform infrared spectroscopy (FTIR) for structural, optical, and chemical properties' study, respectively.

\subsection{X-Ray Diffraction Analysis}

Structural analysis of the sample has been done by powder x-ray diffraction method using a computer-controlled GBC EMMA x-ray diffractometer with $\mathrm{Cu} K_{\alpha}$ radiation (under operating voltage of $40 \mathrm{kV}$, current of $40 \mathrm{~mA}$ and maximum temperature of $1600^{\circ} \mathrm{C}$ ) using wavelength of $1.5406 \AA$. The scanning angular range was $10^{\circ} \leq 2 \Theta \leq 70^{\circ}$ to get possible fundamental picks for each sample.

The results of x-ray diffraction for increasing growth temperatures are shown in Fig. 1, $a$. The XRD spectra show typical hexagonal wurtzite-type structure of $\mathrm{ZnO}$ with respect to standard card (JCPDS No. 79-0208). The crystallite sizes of $\mathrm{ZnO}$ were calculated using the Debye-Scherer's formula [24]: $D=0.9 \lambda /(\beta \cos \theta)$, where $\lambda$, $\theta$ and $\beta$ are the x-ray wavelength (1.54056 $\AA)$, Bragg's diffraction angle and line width at half-maximum of the $\mathrm{ZnO}$ (101) diffraction peak, respectively. The crystallite size of the $\mathrm{ZnO}$ nanoparticles increased from 10.08 to $37 \mathrm{~nm}$ with an increase in growth temperature from 100 to $150^{\circ} \mathrm{C}$. It was observed that the XRD-peak broadening decreases, while the intensity increases confirming an improved crystal quality with increased growth temperature. Expan-
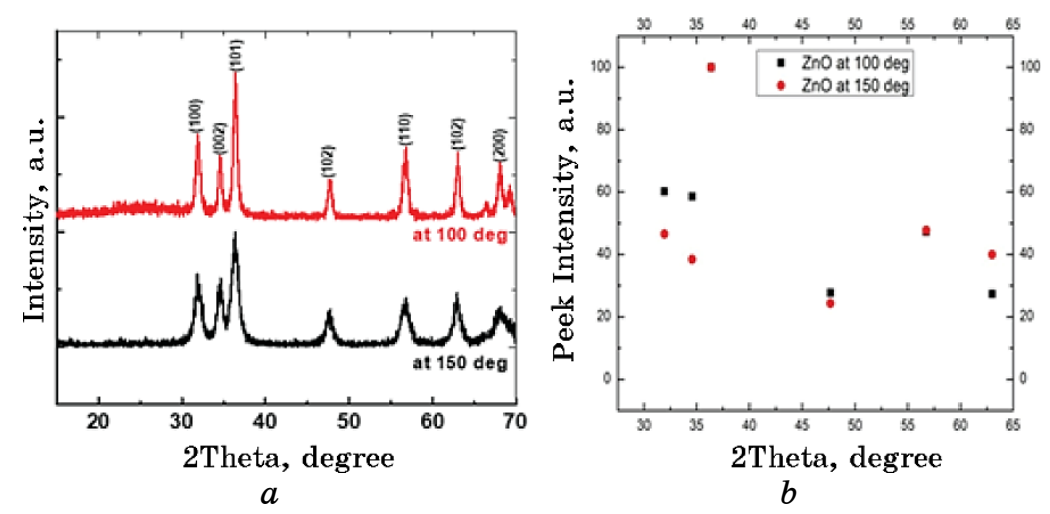

Fig. 1. (a) X-ray powder diffraction pattern and (b) comparison of changes in peak intensity and positions for $\mathrm{ZnO}$ nanoparticles prepared at $100^{\circ} \mathrm{C}$ and $150^{\circ} \mathrm{C}$ growth temperature. 
sion of the lattice due to increased growth temperature is responsible for increase in lattice parameters $a$ and $c$ determined by the following equation:

$$
\frac{1}{d^{2}}=\frac{4}{3}\left(\frac{h^{2}+h k+k^{2}}{a^{2}}\right)+\frac{l^{2}}{c^{2}},
$$

where $d$ is interplanar spacing, $h, k, l$ are the Miller indices, $a, c$ are the lattice parameters. For hexagonal structure, $a=b \neq c$ and $\alpha=\beta=90^{\circ}, \gamma=120^{\circ}$.

The volume of the unit cell was calculated by using the following formula [24]:

$$
V=\frac{\sqrt{3}}{2} a^{2} c
$$

$\mathrm{Zn}-\mathrm{O}$-bond length was calculated by using the following relation [25]:

$$
L=\sqrt{\left[\frac{a^{2}}{3}+\left(\frac{1}{2}-u\right)^{2} c^{2}\right]},
$$

where the $u$ parameter for the wurtzite-type structure is given by

$$
u=\frac{a^{2}}{3 c^{2}}+0.25 \text {. }
$$

\begin{tabular}{|c|c|c|c|c|c|c|c|c|}
\hline \multirow[b]{3}{*}{ Sample } & \multicolumn{4}{|c|}{ Lattice Parameters, $\AA$} & \multirow[b]{3}{*}{ 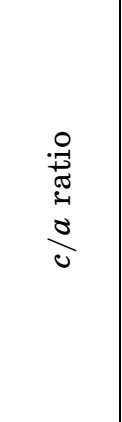 } & \multirow{3}{*}{ 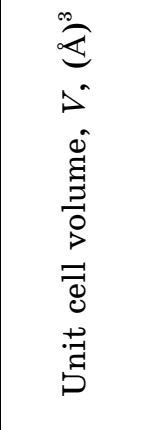 } & \multirow{3}{*}{ 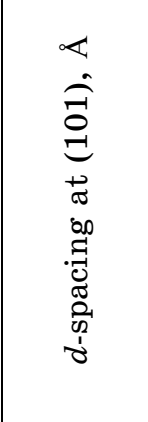 } & \multirow{3}{*}{ 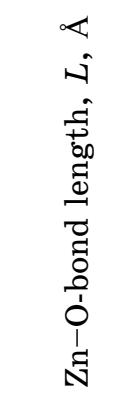 } \\
\hline & \multicolumn{2}{|c|}{$a=b$} & \multicolumn{2}{|c|}{$c$} & & & & \\
\hline & 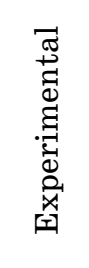 & 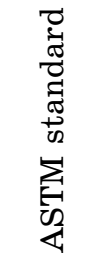 & 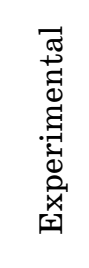 & 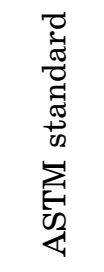 & & & & \\
\hline at $100^{\circ} \mathrm{C}$ & 3.25 & & 5.22 & & 1.6062 & 47.7494 & 2.47492 & 1.9795 \\
\hline at $150^{\circ} \mathrm{C}$ & 3.26 & $0.4 t$ & 5.23 & 0.401 & 1.6043 & 48.1357 & 2.46949 & 1.9848 \\
\hline
\end{tabular}

Now, different measured properties of nanostructured $\mathrm{ZnO}$ materials have been calculated and tabulated in Table. The $c / a$ ratio is ob-

TABLE. Different measured properties of $\mathrm{ZnO}$ nanoparticles. 
served to decrease with the increasing the growth temperature. The average ratio of lattice parameters, $c / a$, is of approximately 1.60525 that is slightly greater than the ASTM standard value (1.60215). The interplanar spacing has been decreased due to small shift in $2 \theta$ due to increase in growth temperature. The unit-cell volume and $\mathrm{Zn}-\mathrm{O}$-bond length were found to be increased with the increase of synthesis temperature. Similar trend was observed from the particle size data. It is observed that the values of lattice parameters, volume of unit cell and interplanar spacing are in good agreement with the ASTM standards. Again, the values of $\mathrm{Zn}-\mathrm{O}$-bond length are also in good agreement with the result obtained by Ilican et al. [26].

Figure 1, $b$ shows how the peak intensity of the particles decreases continuously with the increase in growth temperature and as width of the peaks gets narrower. Maximum emission intensity was observed for growth temperature of $150^{\circ} \mathrm{C}$, while maximum peak width was at $100^{\circ} \mathrm{C}$. As the particle becomes thicker, the crystalline quality is improved, and preferred orientation of the grain is enhanced. The decrease of the FWHM with increasing growth temperature could be due to the coalescence of grains at higher temperatures leading to increase in the average crystallite size. According to Ostwald ripening, the increase in the particle size is due to the merging of the smaller particles into larger ones [27].

\subsection{Optical Properties Analysis}

The optical properties of the synthesized $\mathrm{ZnO}$ nanoparticles have been studied by using the UV-Vis spectroscopy. The absorbance, reflectance and transmittance are recorded with the variation of incident-photon wavelength in the range from $190 \mathrm{~nm}$ to $1100 \mathrm{~nm}$
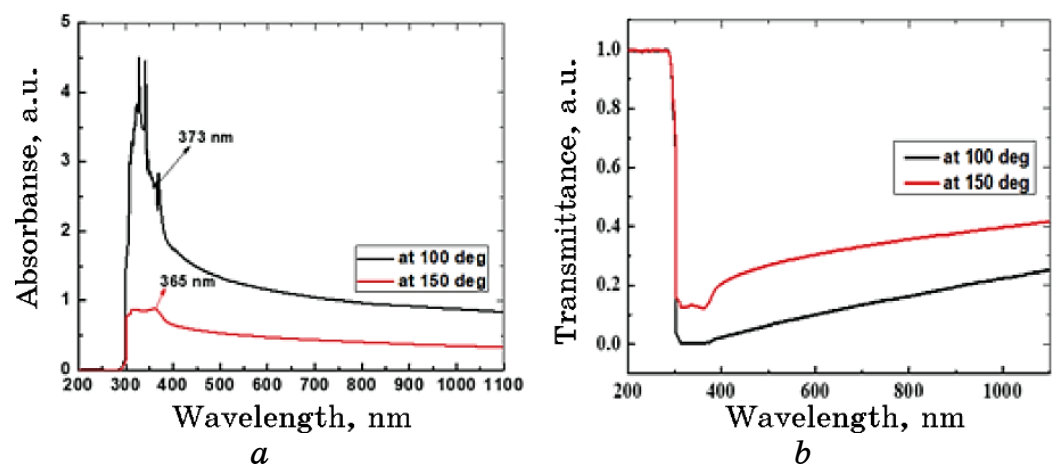

Fig. 2. UV-Vis (a) absorption spectra and $(b)$ transmission spectra of $\mathrm{ZnO}$ nanoparticles prepared at temperatures of $100^{\circ} \mathrm{C}$ and $150^{\circ} \mathrm{C}$. 
with $1 \mathrm{~nm}$ wavelength step. By using the absorbance, reflectance and transmittance data, the extinction coefficient, optical band gap, refractive indices, and dielectric constants have been calculated.

UV-Vis spectrum in the absorption mode is measured at room temperature for different $\mathrm{ZnO}$ samples while dispersed in methanol and shown in Fig. 2, $a$.

Absorption peaks are centred at $373 \mathrm{~nm}, 365 \mathrm{~nm}$ at $100^{\circ} \mathrm{C}$ and $150^{\circ} \mathrm{C}$ temperatures, respectively, that are considerably blue-shifted relative to the absorption onset of bulk $\mathrm{ZnO}$ because of the quantum size effects were found. This UV-absorption peak confirms the formation of nanosize zinc-oxide particles [28].

Figure 2, $b$ shows the transmittance spectra for the $\mathrm{ZnO}$ nanoparticles. The sharp drop in transmission at relatively short wavelengths compared to the bulk material is indicative of the formation of $\mathrm{ZnO}$ nanocrystals. The transmittance spectra show a sharp decrease in the transmittance, and after crossing a certain wavelength, it does not show the same character and becomes almost straight line.

The optical transition involved in the thin films can be determined on the basis of the dependence of absorption coefficient $(\alpha)$ on $h v$ by using the Tauc relation: $\alpha h v=B\left(h v-E_{g}\right)^{n}$, where $E_{g}$ is the optical energy gap between the bottom of the conduction band and the top of the valence band, the value of $B$ is a constant, and $n$ is the index, which can assume value of 0.5 for indirect transition and 2 for direct transition.

The energy band gaps $E_{g}$ for all the samples were obtained from the plot of $(\alpha h v)^{2}$ against $h v$ by superimposing an extra-plotted line on the energy axis at straight line portion, as shown in Fig. $3, a$. The values of $E_{g}$ obtained were of around $3.60 \mathrm{eV}$ and $3.05 \mathrm{eV}$ at two different temperatures. It was observed that, by increasing the temperature, the grain size of the particles increases but the band gap decreases (Fig. 3, $b$ ). It is also a size-dependent property of nanomaterials, which testifies to that, by decreasing the size of nanomaterials, the band gap of the particles increases in a significant way [29].

The extinction coefficient, $k$, can be calculated from $\alpha$ using the relation: $\alpha=4 \pi k / \lambda$, where, $\lambda$ is the wavelength. The variations of $k$ with $h v$ for copper-oxide nanoparticles at different temperatures are shown in Fig. 4, a. It is seen from the plot that the extinction coefficient, $k$, decreases with the increase in photon energy.

The refractive index $(n)$ of the nanoparticles was calculated from the following equation:

$$
n=\frac{1+R}{1-R}+\left(\frac{4 R}{(1-R)^{2}}-k\right)^{1 / 2},
$$

where $R$ is the reflectance and $k$ is the extinction coefficient. 
From the graph (Fig. 4, b), it was observed that the refractive
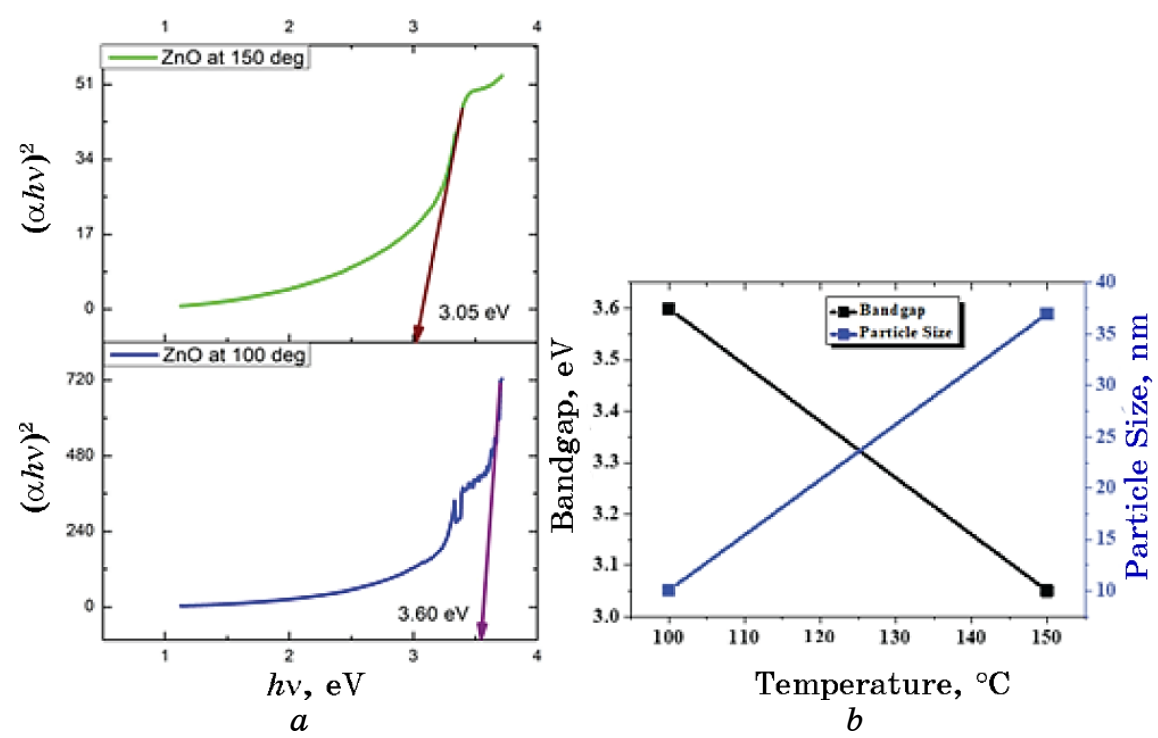

Fig. 3. (a) Band gap determined from the Tauc plot and (b) relation between band gap and particle size of the $\mathrm{ZnO}$ nanoparticles at different temperatures.

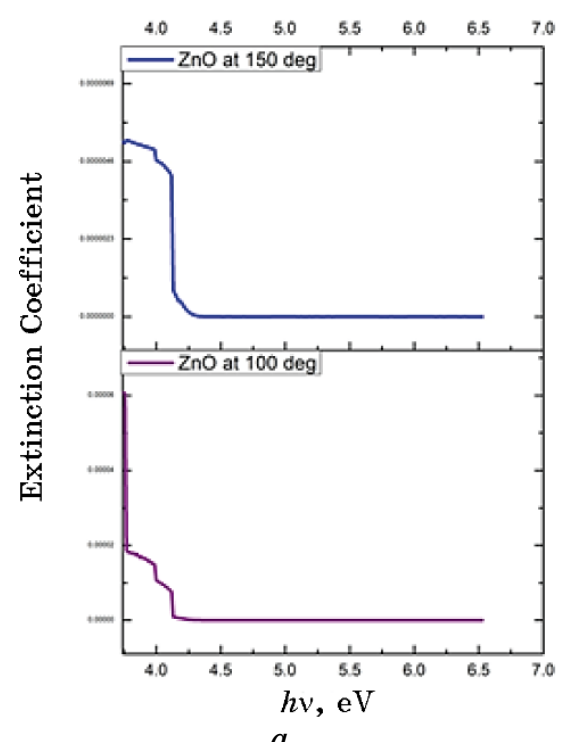

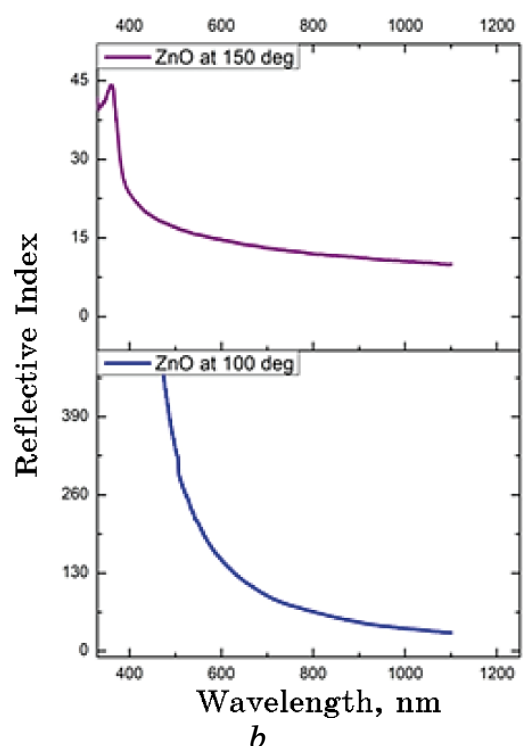

$b$

Fig. 4. (a) Variation of extinction coefficient with incident-photon energy and $(b)$ variation of extinction coefficient with incident-photon wavelength for $\mathrm{ZnO}$ at different temperatures. 


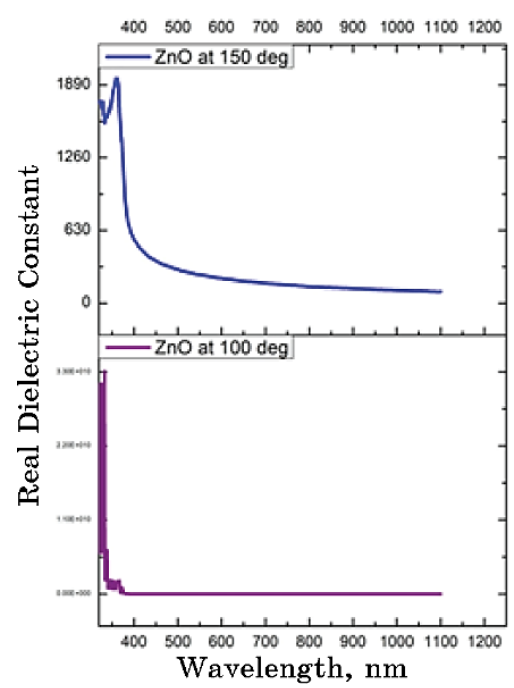

$a$

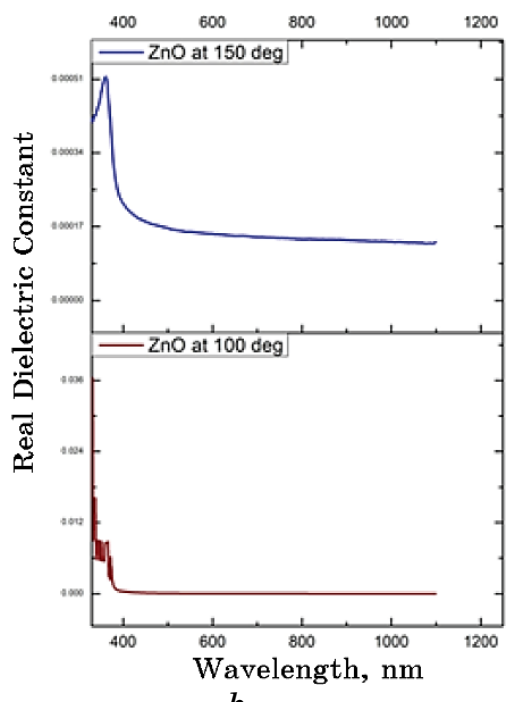

$b$

Fig. 5. Incident-photon wavelength-dependent (a) real and (b) imaginary dielectric constants for $\mathrm{ZnO}$ nanoparticles at different temperature.

index of the particles decreases exponentially by increasing the wavelength of the incident photon.

The dielectric constant of material is a quantity related to the refractive index. It is a measure of insulation. The dielectric constant of $\mathrm{ZnO}$ nanoparticles can be expressed by the relation:

$$
\varepsilon=\varepsilon_{r}+i \varepsilon_{i},
$$

where $\varepsilon_{r}$ and $\varepsilon_{i}$ are the real and imaginary parts of the dielectric constant, respectively. The real and imaginary dielectric constants can be calculated with the equations as follow below:

$$
\varepsilon_{r}=n^{2}-k^{2}, \varepsilon_{i}=2 n k .
$$

Now, we can see the figure of dielectric constant $v s$. wavelength in Fig. 5, $a, b$. It is observed that real dielectric constant increases with the increase in wavelength.

\subsection{Fourier-Transform Infrared (FTIR) Spectroscopy}

Fourier-transform infrared (FTIR) spectroscopy study of ZnO nanoparticles at different temperature was performed for the compositional study of ZnO nanomaterials. The FTIR spectra of the samples 


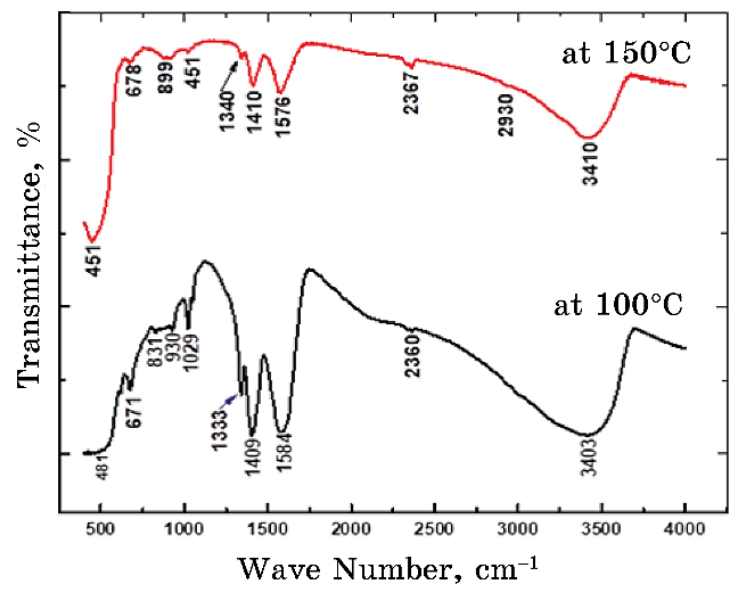

Fig. 6. FTIR spectrum of $\mathrm{ZnO}$ nanoparticles at temperatures of $100^{\circ} \mathrm{C}$ and $150^{\circ} \mathrm{C}$.

were recorded at room temperature using the IR Tracer-100 in the wave-number range of $400-4000 \mathrm{~cm}^{-1}$ and presented in Fig. 6. Absorption peaks were found approximately at 485, 1022, 1406, 1587 and $3406 \mathrm{~cm}^{-1}$ from FTIR spectrum. In the given figures on the axis of wave number, the absorbance peaks around $3400 \mathrm{~cm}^{-1}$, approximately $1587 \mathrm{~cm}^{-1}, 1022 \mathrm{~cm}^{-1}$, and approximately $485 \mathrm{~cm}^{-1}$ are the peaks representing the hydroxyl $(-\mathrm{OH})$ groups, organic group of carbon (carbonyl carbon $\mathrm{C}=\mathrm{O}$ ), probably due to the nitrate $\left(\mathrm{NO}_{3} \downarrow\right)$ group, and zinc and oxygen $(\mathrm{Zn}-\mathrm{O})[30,31]$ groups, respectively. The results show the incomplete removal of organic solvent. However, more organic-solvent presence is observed at high growth temperature, indicating presence of more impurity compared to lower growth temperature. Therefore, it can be concluded that no significant impurities are present in the sample.

\section{CONCLUSIONS}

The ZnO nanoparticles have been synthesized by using an easy, cheap, and rapid green method, namely, hydrothermal method with the assistance of stainless-steel autoclave at two different temperatures maintained at furnace. The influences of temperature and some other growth parameters on structural, optical and some chemical properties of metal-oxide nanoparticles $(\mathrm{ZnO})$ were investigated by using some advanced techniques like x-ray diffraction (XRD), UV-Vis spectroscopy and Fourier-transform infrared (FTIR) spectroscopy. XRD analysis identified the hexagonal wurtzite-type structure of $\mathrm{ZnO}$ nanoparticles and indicated that the grain size of 
the crystal increased from $10.08 \mathrm{~nm}$ to $37 \mathrm{~nm}$ along with the elevated growth temperature from $100^{\circ} \mathrm{C}$ to $150^{\circ} \mathrm{C}$. It was also observed that the XRD-peak intensity decreased with the higher growth temperature that confirmed an improved crystallinity at lower temperature. From the UV-Vis spectroscopy, it was observed that the absorption peaks are centred at $373 \mathrm{~nm}$ and $365 \mathrm{~nm}$ at $100^{\circ} \mathrm{C}$ and $150^{\circ} \mathrm{C}$ temperatures, respectively, that is considerably blue-shifted. The transmittance spectra showed a sharp decrease in the transmittance after crossing a certain wavelength that was the strong evidence of cut-off wavelength for the transmittance of $\mathrm{ZnO}$ nanoparticles. The UV-Vis-study depicted increase in grain size, but the decrease in band gap with the elevated temperature that is the obvious indication for the size-dependent property of nanomaterials. The transmission of FTIR spectra confirmed the presence of the hydroxyl $(-\mathrm{OH})$ groups, organic group of carbon (carbonyl carbon $\mathrm{C}=\mathrm{O})$, probably due to the nitrate $\left(\mathrm{NO}_{3} \downarrow\right)$ group, and zinc and oxygen $(\mathrm{Zn}-\mathrm{O})$ groups, respectively. The results showed the incomplete removal of organic solvent. However, more organic-solvent presence was observed at high growth temperature, indicating presence of more impurity compared to lower growth temperature. Hence, it can be concluded that the size of the $\mathrm{ZnO}$ nanoparticles can be controlled by the synthesis temperature.

\section{ACKNOWLEDGEMENT}

Author A.K.M. Shahabuddin wants to acknowledge the financial support of the Bangladesh Ministry of Science and Technology (MOST) through the National Science and Technology (NST) Fellowship.

\section{REFERENCES}

1. A. H. Lu, E. L. Salabas, and F. Schüth, Angewandte Chemie International Edition, 46, No. 8: 1222 (2007); doi:10.1002/anie.200602866

2. Synthesis, Properties, and Applications of Oxide Nanomaterials (Eds. J. Rodriguez and M. Fernándes-Garcia) (Hoboken, NJ, USA: WileyInterscience: 2007).

3. J. H. Lee, D. N. Liu, and S. T. Wu, Introduction to Flat Panel Displays (Chichester, UK: John Wiley \& Sons: 2008).

4. Metal Oxides: Chemistry and Applications (Ed. J. L. G. Fierro) (Boca Raton, FL: CRC Press: 2006).

5. $\quad$ C. Wöll, Progress in Surface Science, 82, No. 2: 55 (2007); doi:10.1016/j.progsurf.2006.12.002

6. A. P. Alivisatos, D. J. Milliron, A. Meisel, E. C. Scher, and L. Manna, Nature Materials, 2, No. 6: 382 (2003); doi:10.1038/nmat902

7. K. Hümmer, physica status solidi (b), 56, No. 1: 249 (1973); doi:10.1002/pssb.2220560124 
8. B. Monemar, Phys.Rev. B, 10, No. 2: 676 (1974); doi:10.1103/PhysRevB.10.676

9. C. M. Niemeyer, Angewandte Chemie International Edition, 40, No. 22: 4128 (2001); doi:10.1002/1521-3773(20011119)40:22<4128::AID-ANIE4128>3.0.CO;2-S

10. D. J. Beebe, J. M. Bauer, R. H. Liu, J. S. Moore, C. Devadoss, B.-H. Jo, and Q. Yu, Nature, 404, No. 6778: 588 (2000); doi:10.1038/35007047

11. M. H. Huang, S. Mao, H. Feick, H. Yan, Y. Wu, H. Kind, E. Weber, R. Russo, and P. Yang, Science, 292, No. 5523: 1897 (2001); doi:10.1126/science.1060367

12. S. Fujita, S.-W. Kim, M. Ueda, and S. Fujita, Journal of Crystal Growth, 272, No. 1: 138 (2004); https://doi.org/10.1016/j.jcrysgro.2004.08.078

13. P. X. Gao and Z. L. Wang, The Journal of Physical Chemistry B, 108, No. 23: 7534 (2004); doi:10.1021/jp049657n

14. N. Singh, R. M. Mehra, A. Kapoor, and T. Soga, Journal of Renewable and Sustainable Energy, 4, No. 1: 013110 (2012); doi:10.1063/1.3683531

15. R. Song, Y. Liu, and L. He, Solid State Sciences, 10, No. 11: 1563 (2008); https://doi.org/10.1016/j.solidstatesciences.2008.02.006

16. D. B. Bharti and A. V. Bharati, Luminescence, 32, No. 3: 317 (2017); doi:10.1002/bio. 3180

17. N. Sharma, S. Kumar, and J. Kumar, Integrated Ferroelectrics, 186, No. 1: 115 (2018); doi:10.1080/10584587.2017.1370333

18. D. Ramimoghadam, M. Z. Bin Hussein, and Y. H. Taufiq-Yap, Chemistry Central Journal, 7, No. 1: 1 (2013); doi:10.1186/1752-153X-7-136

19. P. M. Aneesh, K. A. Vanaja, and M. K. Jayaraj, Synthesis of ZnO Nanoparticles by Hydrothermal Method (Conference Proceedings), vol. 6639, p. 66390J.

20. K. Elen, H. Van den Rul, A. Hardy, M. K. Van Bael, J. D'Haen, R. Peeters, D. Franco, and J. Mullens, Nanotechnology, 20, No. 5: 055608 (2009); doi:10.1088/0957-4484/20/5/055608

21. A. B. Moghaddam, T. Nazari, J. Badraghi, and M. Kazemzad, International Journal of Electrochemical Science, 4, No. 2: 247 (2009).

22. L. F. Koao, F. B. Dejene, R. E. Kroon, and H. C. Swart, Journal of Luminescence, 147: 85 (2014); https://doi.org/10.1016/j.jlumin.2013.10.045

23. M. Søndergaard, E. D. Bøjesen, M. Christensen, and B. B. Iversen, Crystal Growth \& Design, 11, No. 9: 4027 (2011); doi:10.1021/cg200596c

24. B. D. Cullity, Elements of X-Ray Diffraction (New York: Addison-Wesley Publisher: 1956).

25. C. S. Barrett and T. B. Massalski, Structure of Metals: Crystallographic Methods, Principles, and Data (New York: Pergamon: 1980).

26. S. Ilican, Y. Caglar, and M. Caglar, Journal of Optoelectronics and Advanced Materials, 10, No. 10: 2578 (2008).

27. K. K. Nanda, F. E. Kruis, and H. Fissan, Phys. Rev. Lett., 89, No. 25: 256103 (2002); doi:10.1103/PhysRevLett.89.256103

28. L. E. Greene, B. D. Yuhas, M. Law, D. Zitoun, and P. Yang, Inorganic Chemistry, 45, No. 19: 7535 (2006); doi:10.1021/ic0601900

29. E. A. Meulenkamp, The Journal of Physical Chemistry B, 102, No. 29: 5566 (1998); doi:10.1021/jp980730h

30. H. I. K, J. M. C, D. J. K, and M. G. S, Journal of Ceramic Processing Research, 3, No. 3: 146 (2002); http://www.jcpr.or.kr/journal/archive/view/101\#

31. X. M. Sui, C. L. Shao, and Y. C. Liu, Applied Physics Letters, 87, No. 11: 113115 (2005); doi:10.1063/1.2048808 